\title{
A formação de tradutores em periódicos acadêmicos brasileiros online sobre Estudos da Tradução (1996-2016): mapeamento e descritores
}

Patrícia Rodrigues Costa e Andréia Guerini*

\section{Introdução}

A formação de tradutores em instituições de ensino brasileiras em cursos de graduação tornou-se possível somente após a publicação da Lei de Diretrizes e Bases de 1968, que permitiu maior autonomia às instituições de ensino superior na criação de graduações, tornando possível a criação da modalidade bacharelado para cursos tradicionalmente ofertados somente como licenciatura. Após pouco mais de meio século, temos, no território brasileiro, aproximadamente 30 bacharelados destinados à formação de tradutores, em sua maioria oferecidos por instituições privadas de ensino, com destaque para o estado de São Paulo (COSTA, 2018; COSTA; GUERINI; PEREIRA, 2019). Mais recentemente, além das graduações, tivemos a criação de programas de pós-graduações stricto sensu (PGET, POSTRAD, TradUSP, POET), e a organização de eventos e de periódicos acadêmicos destinados às discussões dos mais diversos temas relativos aos Estudos da Tradução. Contudo, pesquisas sobre a formação de tradutores datam da década de 1970 em programas de pós-graduação brasileiros.

O aumento das pesquisas no sub-ramo Formação de Tradutores, em inglês Translator Training (HOLMES, 1994, p. 77), nos últimos anos no Brasil

\footnotetext{
${ }^{*}$ Universidade de Brasília e Universidade Federal de Santa Catarina.
} 
e no exterior demonstra a relevância de se pensar a maneira como os futuros tradutores são formados, isto é, questões relativas, por exemplo, à Pedagogia da Tradução, à sua Didática, aos currículos ofertados por instituições nacionais, à formação dos professores dos cursos de Tradução, para citar somente algumas (COSTA, 2018). Assim, o presente artigo busca responder ao seguinte questionamento: "O que temos publicado sobre formação de tradutores em formato de artigos nos periódicos acadêmicos online brasileiros dedicados aos Estudos da Tradução?".

Esse artigo busca ser o lugar de resposta a esse questionamento. Para tanto, 1) identifica os periódicos acadêmicos brasileiros online com publicações sobre a temática da formação de tradutores; 2) apresenta o levantamento e o mapeamento dos artigos publicados nos periódicos acadêmicos brasileiros online da área dos Estudos da Tradução acerca da formação de tradutores no arco temporal de 20 anos, de 1996 a 2016 e 3) discute a escolha dos descritores para a indexação dos artigos.

Esse artigo visa ser também um dos possíveis desdobramentos aos artigos publicados por Pagano e Vasconcellos $(2003$, 2006) e Alves e Vasconcellos (2016), pois ao traçarmos o panorama dos artigos publicados em periódicos acadêmicos brasileiros com a temática da formação de tradutores, buscamos além de quantificar os artigos sobre o tema em questão, verificar e analisar os descritores utilizados para indexar tais publicações, o que justifica sua natureza bibliométrica. Assim, pode ser entendido como uma contribuição para a consolidação das pesquisas relacionadas à formação de tradutores ampliando uma subárea da Historiografia da Tradução.

\section{Método de pesquisa}

Conforme explicitado anteriormente, buscamos, por meio de um levantamento, analisar de modo quantitativo e qualitativo os artigos publicados de 1996 a 2016 em periódicos online acadêmicos brasileiros dedicados aos Estudos da Tradução sobre a temática da formação de tradutores. A justificativa da delimitação deste artigo se dá em função do interesse das autoras sobre a temática formação de tradutores e sua relevância 
se encontra na identificação do aumento do interesse dos pesquisadores nos últimos anos em relação à formação de tradutores.

Após termos definido o corpus inicial de investigação, utilizamos a ferramenta de busca disponível nos sites de cada periódico por descritores que atuaram como "filtros" desses portais acadêmicos para identificar a ocorrência de artigos relacionados à formação de tradutores; no caso de periódicos que não disponibilizam essa ferramenta, a busca foi realizada manualmente. As palavras-chave utilizadas foram: "Ensino de Tradução", "Pedagogia da Tradução", "Didática da tradução", "formação de tradutores", "tradutor(es) em formação", "treinamento de tradutores".

Entre os artigos encontrados, não foram considerados artigos relacionados ao ensino de língua estrangeira (LE), à formação de tradutores/intérpretes de LIBRAS, à formação de intérpretes, à formação de audiodescritores. Posteriormente, os títulos, as palavras-chave e o conteúdo do artigo foram examinados com vistas a verificar se o artigo em questão realmente versava sobre a formação de tradutores.

Em seguida, as edições online disponíveis de cada periódico foram averiguadas tendo por objetivo identificar mais algum artigo que pudesse compor o corpus e que por algum motivo a ferramenta de busca não o tenha filtrado.

Após essa averiguação, as edições de cada periódico foram quantificadas e inseridas em planilhas eletrônicas, o que levou também à quantificação dos artigos por ano. Por último, foram quantificados os artigos com a temática da formação de tradutores. Na fase final de levantamento e mapeamento, foram explorados e analisados os descritores (palavras-chave, título) dos artigos levantados tanto no aspecto quantitativo quanto qualitativo.

\section{Análise quantitativa dos dados}

Utilizamos a análise quantitativa para (1) definir o número de periódicos a serem analisados, (2) identificar os periódicos com publicações com a temática da formação de tradutores, (3) verificar o total de artigos publicados por periódicos online e (4) delimitar o corpus de análise dos descritores. Em 
suma, para levantar o número de artigos publicados com a temática da formação de tradutores.

Assim, de modo a melhor delimitar nossa pesquisa, procuramos identificar os periódicos brasileiros dedicados aos Estudos da Tradução, como pode ser observado no Quadro 1.

Quadro 1 - Periódicos dedicados aos Estudos da Tradução

\begin{tabular}{|c|c|c|c|c|c|}
\hline & Periódicos & Instituição & ISSN & $\begin{array}{l}\text { Período de } \\
\text { publicação }\end{array}$ & Observação \\
\hline 1) & Belas Infiéis & UnB & $2316-6614$ & 2012 - atual & \\
\hline 2) & $\begin{array}{l}\text { Cadernos de Literatura } \\
\text { em Tradução }\end{array}$ & USP & $2359-5388$ & 1997 - atual & \\
\hline 3) & Cadernos de Tradução & UFSC & $2175-7968$ & 1996 - atual & $\begin{array}{l}\text { Passou a ser } \\
\text { indexada pelo } \\
\text { Scielo em } 2016 .\end{array}$ \\
\hline 4) & Cadernos de Tradução & UFRGS & $1807-9873$ & 1998 - atual & \\
\hline 5) & In-Traduções & UFSC & 2176-7904 & $2009-2015$ & Descontinuado \\
\hline 6) & Non plus & USP & $2316-3976$ & 2012 - atual & \\
\hline 7) & Ronái & UFJF & $2318-3446$ & 2006 - atual & \\
\hline 8) & Scientia Traductionis & UFSC & $1980-4237$ & $2005-2014$ & Descontinuado \\
\hline 9) & TradTerm & USP & $2317-9511$ & 1994 - atual & \\
\hline 10) & $\begin{array}{l}\text { Tradução \& } \\
\text { Comunicação: Revista } \\
\text { Brasileira de Tradutores }\end{array}$ & $\begin{array}{l}\text { Anhangue } \\
\text { ra }\end{array}$ & $2178-6976$ & $1981-2013$ & Descontinuado \\
\hline 11) & Tradução em Revista & PUC-Rio & 1808-6195 & 2004 - atual & \\
\hline 12) & Traduzires & UnB & $2238-7749$ & $2012-2013$ & Descontinuado \\
\hline 13) & Translatio & UFRGS & $2236-4013$ & 2011 - atual & \\
\hline 14) & Transversal & UFC & $2446-8959$ & 2015 - atual & \\
\hline
\end{tabular}

Fonte: Adaptado de Costa (2018, p. 367-368)

Com esse pano de fundo inicial, buscamos identificar quais dos 14 periódicos disponibilizavam em seu site artigos relacionados à formação de 
tradutores. Com a busca por palavras-chaves, listadas na descrição do método utilizado para essa pesquisa, e a verificação dos artigos dos periódicos reduzimos o nosso corpus para somente sete periódicos acadêmicos: TradTerm; Cadernos de Tradução (UFSC); Tradução em Revista; Rónai; Traduzires; Belas Infiéis; Tradução \& Comunicação. Decidimos, contudo, retirar o periódico Tradução \& Comunicação de nosso corpus uma vez que os artigos disponíveis online datam de 2006 a 2013', mesmo o periódico tendo sido publicado de 1981 a 2013. Ou seja, nosso corpus é composto por seis periódicos online acadêmicos brasileiros: TradTerm; Cadernos de Tradução (UFSC); Tradução em Revista; Rónai; Traduzires; Belas Infiéis.

A partir da definição do corpus, verificamos o número total de artigos publicados por cada periódico entre 1996 e 2016 (Quadro 2).

Quadro 2 - Número total de artigos publicados em periódicos acadêmicos brasileiros disponíveis online com artigos publicados entre 1996 e 2016

\begin{tabular}{|c|c|l|c|}
\hline & Periódico & $\begin{array}{l}\text { Período } \\
(1996-2016)\end{array}$ & $\begin{array}{l}\text { Total de artigos } \\
\text { nesse período }\end{array}$ \\
\hline 1$)$ & TradTerm & $1996-2016$ & 328 \\
\hline 2$)$ & Cadernos de Tradução (UFSC) & $1996-2016$ & 508 \\
\hline 3$)$ & Tradução em Revista & $2006-2016$ & 183 \\
\hline 4$)$ & Rónai & $2006-2016$ & 73 \\
\hline 5$)$ & Traduzires & $2012-2013$ & 31 \\
\hline 6$)$ & Belas Infiéis & $2012-2016$ & 120 \\
\hline \multicolumn{2}{|r|}{ TOTAL } & & $\mathbf{1 . 2 4 3}$ \\
\hline
\end{tabular}

Elaboração: as autoras

\footnotetext{
${ }^{1}$ O periódico Tradução \& Comunicação foi criado pelo Centro Universitário Ibero-Americo (Unibero). Infelizmente, o site da revista não disponibiliza os quatorze primeiros volumes, motivo pelo qual não fará parte de nossa análise. A Unibero foi inicialmente comprada pelo grupo Anhanguera no início dos anos 2000. Em 2013, o grupo Anhanguera foi adquirido pelo Grupo Kroton, o que afetou diretamente a Tradução \& Comunicação. Segundo Karine Taisy Amatuzi, A decisão pela descontinuidade da Tradução \& Comunicação ocorreu no mesmo ano. O periódico Tradução \& Comunicação publicou 124 artigos entre 2006 a 2013, sendo sete sobre algum aspecto acerca da formação de tradutoras e tradutores. AMATUZI, Karine Taisy. Tradução \& Comunicação - v. 1 a v. 14. [mensagem pessoal]. Recebida por: <prcosta1986@gmail.com> em 01 de agosto de 2016.
} 
A partir desses dados gerais, passamos a verificar os artigos publicados por cada periódico brasileiro que teve algum artigo referente à temática da formação de tradutores, de modo a identificar aqueles que não foram localizados inicialmente pela ferramenta de busca de cada periódico. Destacamos que dos 1.243 artigos publicados pelos seis periódicos analisados, somente 61 tinham por temática a formação de tradutores (Gráfico 1). Por esse motivo, passaremos apresentar os dados que serão precedidos de um breve histórico de cada periódico analisado.

Gráfico 1 - Total de artigos vs. Artigos sobre a formação de tradutores publicados em periódicos acadêmicos brasileiros online

Periódicos acadêmicos brasileiros dedicados aos Estudos da Tradução com publicações sobre a formação de tradutores

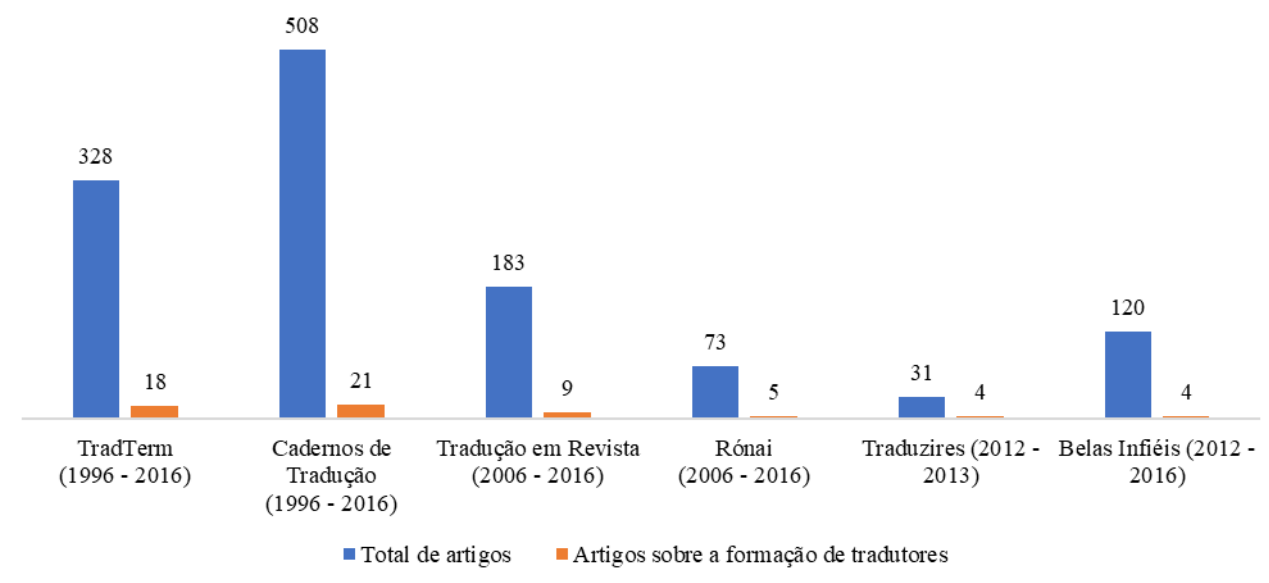

Elaboração: as autoras

\section{TradTerm (USP)}

Publicada desde 1994 pelo Centro Interdepartamental de Tradução e Terminologia (CITRAT-USP), a revista acadêmica TradTerm passou a ser publicada semestralmente a partir de 2010 e desde 2011 está disponível em ambiente eletrônico. Com relação à sua periodicidade, destacamos que a TradTerm teve publicação anual entre 1994 e 1996, sendo publicada semestralmente entre 1997 e 1998, brevemente descontinuada em 1999 e retomada em 2000 com publicação anual e, finalmente, passou a ter publicação semestral em 2009. Desse modo, entre 1994 e 2016 foram 
publicados 28 números, que totalizam 347 artigos. Deste total de artigos publicados, somente 18, distribuídos em nove edições diferentes, versam sobre a formação de tradutores em algum aspecto (Quadro 3); em outras palavras, somente $5,19 \%$ dos artigos publicados na TradTerm.

Quadro 3 - Edições da TradTerm (USP) com artigos sobre aspectos da formação de tradutores

\begin{tabular}{|l|l|c|}
\hline Edição & Artigos publicados & $\begin{array}{l}\text { Artigos sobre a formação } \\
\text { do tradutor }\end{array}$ \\
\hline v.4, n.1 (1997) & 7 & 6 \\
\hline v.4, n.2 (1997) & 9 & 2 \\
\hline v. $6(2000)$ & 7 & 1 \\
\hline v.8 (2002) & 6 & 1 \\
\hline v.10 (2004) & 12 & 2 \\
\hline v.16 (2010) & 19 & 1 \\
\hline v.25 (2015) & 12 & 2 \\
\hline v.26 (2015) & 16 & 2 \\
\hline v.27 (2016) & 14 & 1 \\
\hline
\end{tabular}

Elaboração: as autoras

No Gráfico 2, é possível examinar de maneira mais clara as publicações entre 1996 e 2016, uma vez que inserimos os dados referentes às publicações de cada ano - na linha azul temos a quantidade total de artigos publicados e, na linha laranja, os artigos acerca da formação de tradutores; lembrando que no ano de 1999 não houve publicações do periódico TradTerm. 
Gráfico 2 - Quantidade de artigos publicados por ano no periódico TradTerm (USP)

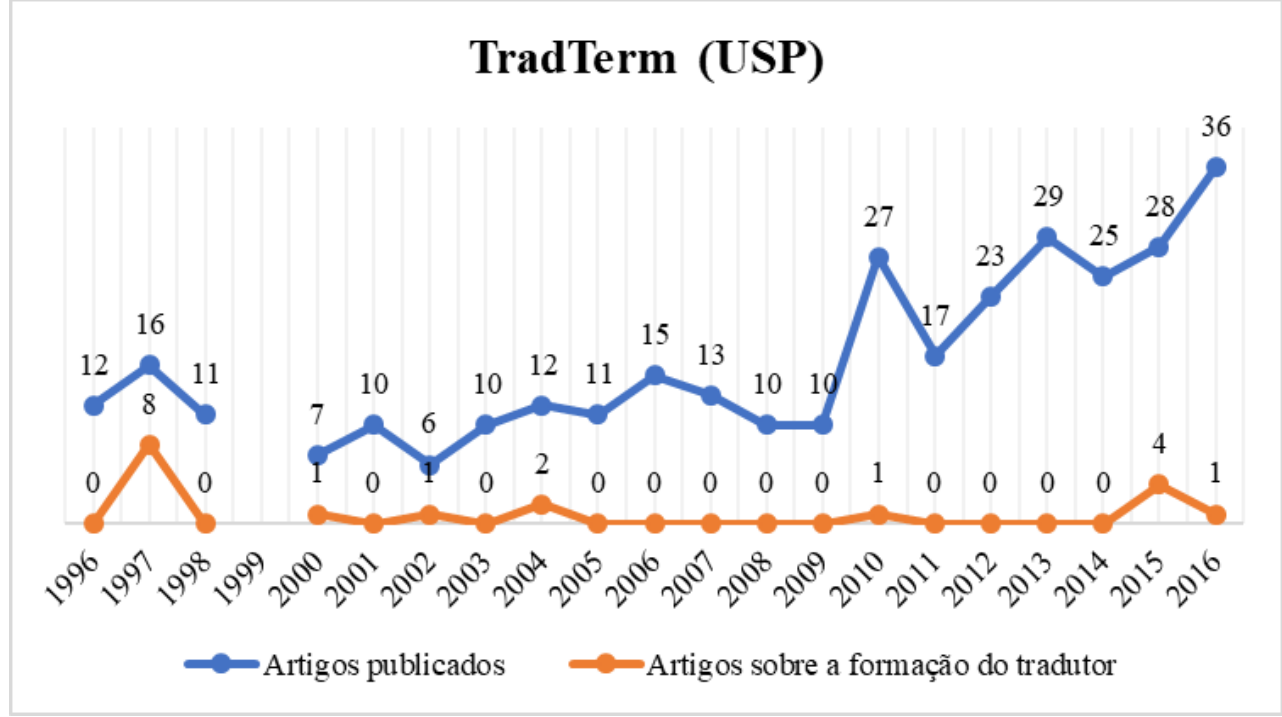

Elaboração: as autoras

Publicando os mais diversos temas relativos aos Estudos da Tradução e à Terminologia, o periódico TradTerm dedicou o volume 4, número 1, publicado em 1997 e organizado por João Azenha Júnior (USP), ao Ensino de Tradução. Assim, todos os seis artigos da seção Tradução versam sobre o tema e o único artigo da seção Terminologia também foi dedicado à formação, mas de terminólogos.

Azenha Júnior destaca, na apresentação desta edição, que a partir do momento que a Tradução foi desvencilhada do ensino de línguas estrangeiras como uma "variante complementar" ou um curso instrumental preparatório para a pós-graduação, o ensino de Tradução passou a sofrer diversas transformações. Motivo pelo qual este número temático poderia "ser visto e estudado como um testemunho de uma evolução não apenas da reflexão sobre ensino de Tradução, mas também - e sobretudo - sobre o cenário que marcou essa reflexão" (AZENHA JÚNIOR, 1997, p. 8).

O ano de 1997 foi o que mais concentrou as publicações sobre a formação de tradutores, pois além da edição organizada por Azenha Júnior, foram publicados mais dois artigos na edição seguinte. Com relação aos dados anuais da TradTerm, podemos verificar no Gráfico 3 a porcentagem de 
artigos publicados sobre a formação de tradutores, com destaque para o ano de 1997, dos 16 artigos publicados 8 tratavam da formação de tradutores, o que equivale a $50 \%$ dos artigos publicados no ano.

Gráfico 3 - Porcentagem de artigos sobre a formação de tradutores publicados por ano no periódico TradTerm (USP)

\section{Porcentagem (\%) de artigos sobre formação de tradutores publicados por ano - TradTerm (USP)}

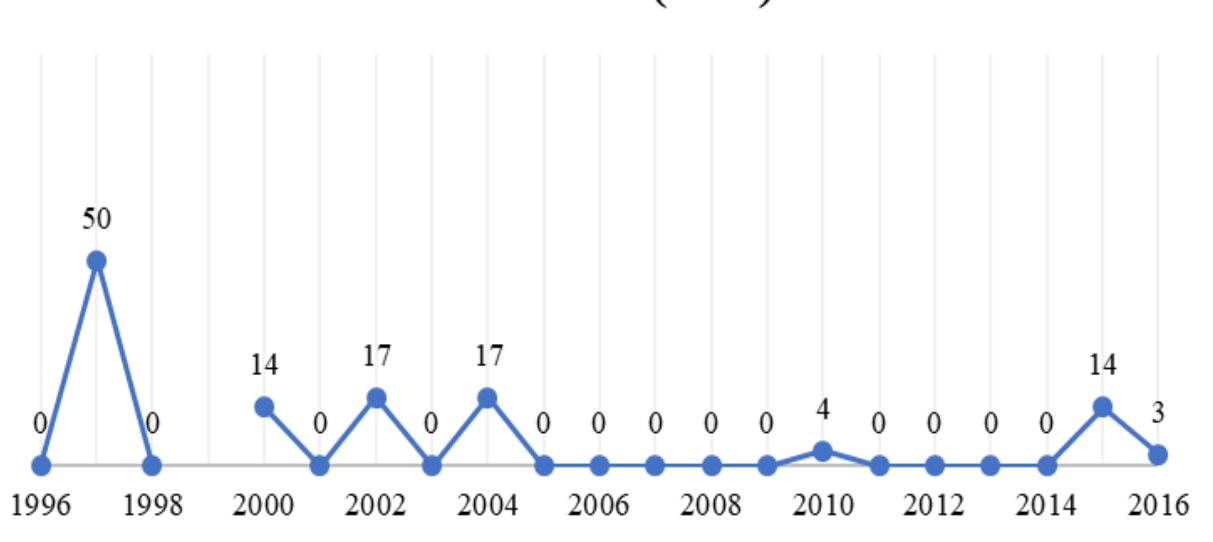

Elaboração: as autoras

Como pode se observar no Gráfico 3, as publicações referentes à formação de tradutores continuaram a ser realizadas no periódico TradTerm de maneira descontínua. Tendo apresentado os dados do periódico TradTerm (USP), passaremos a discutir o levantamento dos dados da revista acadêmica Cadernos de Tradução (UFSC).

\section{Cadernos de Tradução (UFSC)}

Criada em 1996 por professores da Universidade Federal de Santa Catarina (UFSC), a revista acadêmica Cadernos de Tradução passou a ser publicada semestralmente em 2000. Em 2016, com a indexação da Cadernos de Tradução pelo SciELO Brasil, passa a ser quadrimestral com publicações fixas nos meses de janeiro, maio e setembro. De 1996 a 2016, foram publicadas 44 
edições que totalizam 508 artigos, das quais 11 edições contêm artigos sobre a formação de tradutores, contabilizando 21 artigos (Quadro 4).

Quadro 4 - Edições da Cadernos de Tradução (UFSC) com artigos sobre aspectos da formação de tradutores

\begin{tabular}{|l|l|c|}
\hline Edição & Total artigos & $\begin{array}{l}\text { Artigos sobre a formação do } \\
\text { tradutor }\end{array}$ \\
\hline v. 1, n. 3 (1998) & 17 & 1 \\
\hline v. 1, n. $17(2006)$ & 9 & 9 \\
\hline v.1, n. $19(2007)$ & 8 & 2 \\
\hline v. 2, n. $20(2007)$ & 9 & 1 \\
\hline v. 1, n. $27(2011)$ & 13 & 2 \\
\hline v.1, n. 31 (2013) & 10 & 2 \\
\hline v. 2, n. 32 (2013) & 11 & 1 \\
\hline v. 2, n. 34 (2014) & 11 & 1 \\
\hline v. 36, n. 2(2016) & 12 & 1 \\
\hline v. 36, n. 3 (2016) & 11 & 1 \\
\hline
\end{tabular}

Elaboração: as autoras 
O Gráfico 4 apresenta a quantidade de artigos publicados por ano desde o início da publicação do periódico Cadernos de Tradução, bem como o número de artigos que versam sobre a formação de tradutores.

Gráfico 4 - Quantidade de artigos publicados por ano no Cadernos de Tradução (UFSC)

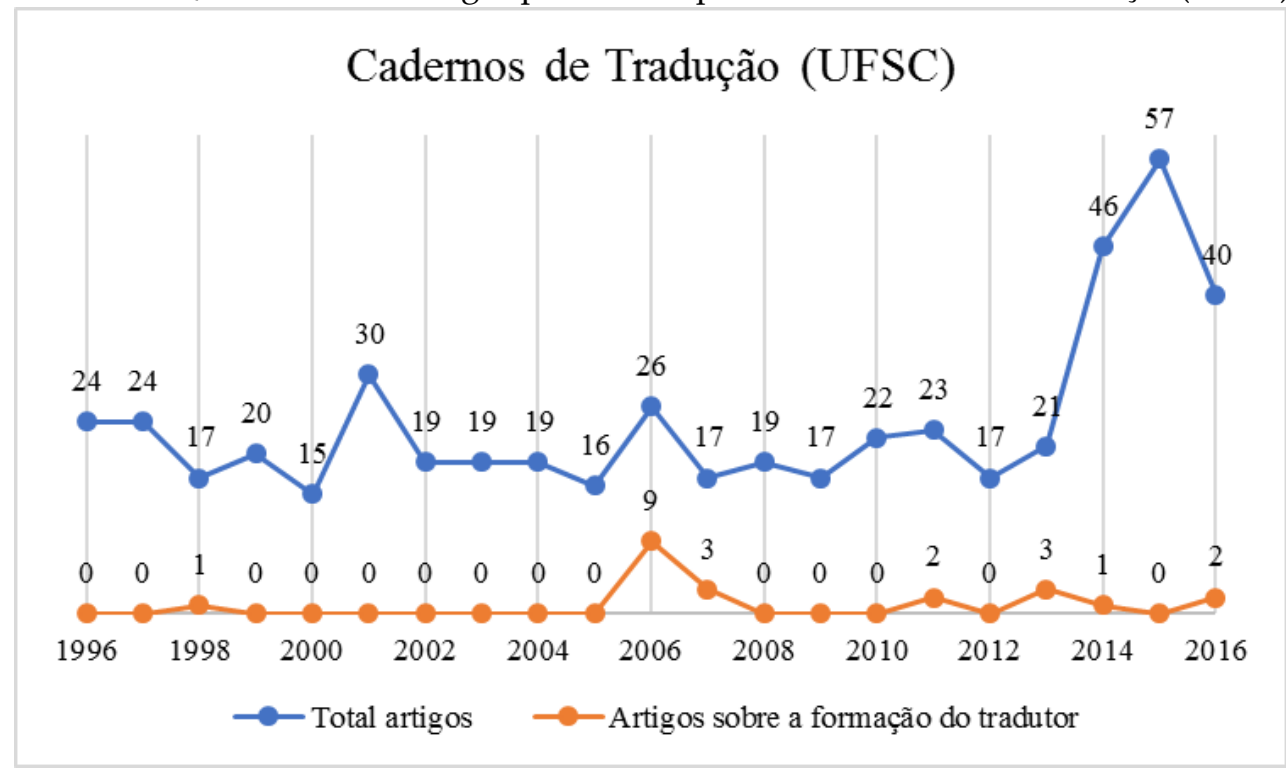

Elaboração: as autoras

Assim, podemos verificar tanto a porcentagem de artigos sobre formação de tradutores publicados de 1996 a 2016 - um total de somente $4,05 \%$ - quanto a porcentagem de publicações conforme o ano, sendo o ano de 2006 o com maior número de textos sobre o tema em relação ao número total de artigos publicados no ano (Gráfico 5). 
Gráfico 5 - Porcentagem de artigos sobre a formação de tradutores publicados por ano no Cadernos de Tradução (UFSC)

\section{Porcentagem (\%) de artigos sobre formação de tradutores publicados por ano - Cadernos de Tradução (UFSC)}

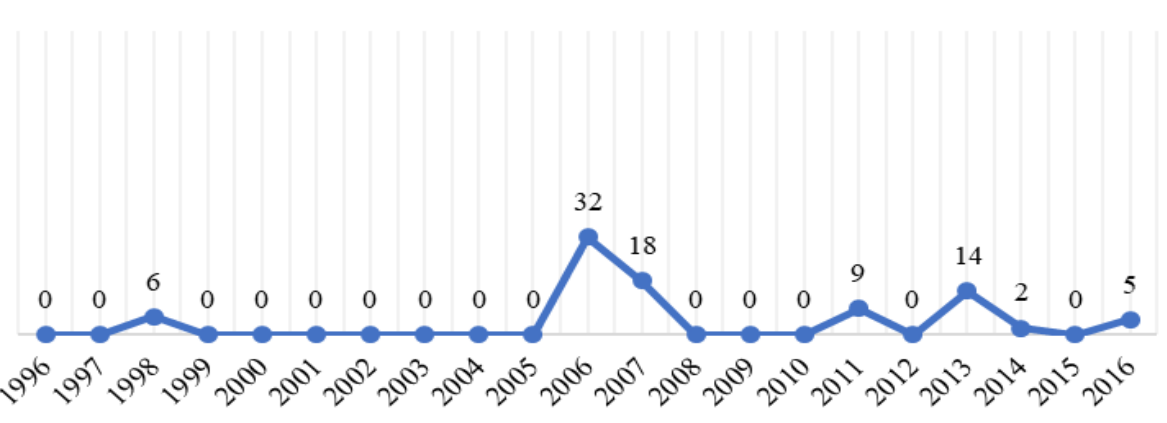

Elaboração: as autoras

Dos 21 artigos sobre formação de tradutores, publicados entre 1996 e 2016, nove foram publicados em 2006 no número temático intitulado “Formação de tradutores e pesquisadores em estudos da tradução" (v. 1, n. 17) organizado por Adriana Pagano (UFMG) e Maria Lúcia Vasconcellos (UFSC). Segundo as organizadoras, a ideia desse número temático surgiu durante o XVII Encontro da Associação Nacional de Pós-Graduação e Pesquisa em Letras e Linguística (ANPOLL) em 2002 e visou "apresentar um recorte da pesquisa em ensino de tradução no cenário nacional" (PAGANO, VASCONCELLOS, 2006, p. 9).

Conforme Pagano e Vasconcellos (2006), durante o encontro da ANPOLL foram debatidas questões relativas à avaliação da década de 1990, as quais estavam alinhadas aos desejos de consolidação da formação de tradutores, o que propiciou o aumento na discussão de fatores pedagógicos e didáticos, tais como: a elaboração de currículos e de ementas, e a autonomia do tradutor em formação. Dessas discussões, foi proposta, em 2003, uma chamada com os seguintes tópicos (PAGANO; VASCONCELLOS, 2006, p. 10):

1) A contribuição da teoria para a formação de tradutores;

2) Direcionalidade na sala de aula de Tradução; 
3) Desenvolvimento de estratégias tradutórias;

4) Novas tecnologias na formação de tradutores;

5) Abordagens textuais e discursivas na formação de tradutores;

6) Programas universitários de formação de tradutores no Brasil;

7) Componentes da competência tradutória;

8) Corpora de aprendizes e o desenvolvimento da competência tradutória;

9) O potencial dos corpora como ferramentas de auxílio à tradução;

10) O papel da lexicografia na elaboração de currículos;

11) A avaliação na formação de tradutores;

12) A dimensão cultural no ensino de Tradução.

De acordo com as organizadoras, foram publicados, em 2006, artigos relacionados a quatro dos temas propostos: 1) à contribuição da teoria para a formação de tradutores, 2) aos programas universitários de formação de tradutores no Brasil, 3) aos componentes da competência tradutória, 4) à lexicografia em sua interrelação com a Tradução. Além dos temas presentes na chamada, houve a inserção da discussão acerca dos programas de pósgraduação no Brasil em razão da criação, em 2003, do primeiro programa de Pós-Graduação em Estudos da Tradução, que foi a Pós-Graduação em Estudos da Tradução (PGET), da Universidade Federal de Santa Catarina.

Pagano e Vasconcellos (2006, p. 17) destacam o anseio de que essa edição temática "venha a contribuir para o avanço das reflexões sobre o ensino de Tradução no nosso meio acadêmico", o que certamente fez, visto que nos últimos anos o interesse acerca da formação de tradutores tem crescido no Brasil.

Nestes 20 anos analisados de publicação da Cadernos de Tradução, as publicações relacionadas ao ensino de Tradução têm ocorrido de maneira contínua nos últimos 5 anos, o que pode demonstrar o aumento do interesse pelo tema. Destacamos que na edição de 2015 (v. 35, n. 2) foram publicados dois artigos sobre a formação de tradutores/intérpretes de Língua Brasileira de Sinais e que em 2016 (v. 36, n. 3) foi publicado um artigo sobre a formação de audiodescritores. 
Tradução em Revista (PUC - Rio)

Criado em 2004 pelo Departamento de Letras da Pontifícia Universidade Católica do Rio de Janeiro (PUC-Rio), o periódico Tradução em Revista passou a ser publicado exclusivamente por meio eletrônico em 2006, data que passamos a ter acesso às publicações em seu site. A partir de 2009, sua periodicidade passou de anual para semestral. Entre 2006 e 2016, foram publicadas 19 edições, totalizando 184 artigos, dos quais 11 tratam da formação de tradutores (Quadro 6, Gráfico 7), o que equivale a 5,98\% do total.

Quadro 6 - Edições da Tradução em Revista (PUC-Rio) com artigos sobre aspectos da formação de tradutores

\begin{tabular}{|l|l|c|}
\hline Edição & Total artigos & $\begin{array}{l}\text { Artigos sobre a formação } \\
\text { do tradutor }\end{array}$ \\
\hline $2009(7)$ & 12 & 1 \\
\hline $2012(13)$ & 8 & 7 \\
\hline $2013(14)$ & 14 & 2 \\
\hline $2014(17)$ & 9 & 1 \\
\hline
\end{tabular}

Elaboração: as autoras 
Gráfico 7 - Quantidade de artigos publicados por ano no periódico Tradução em Revista (PUC - Rio)

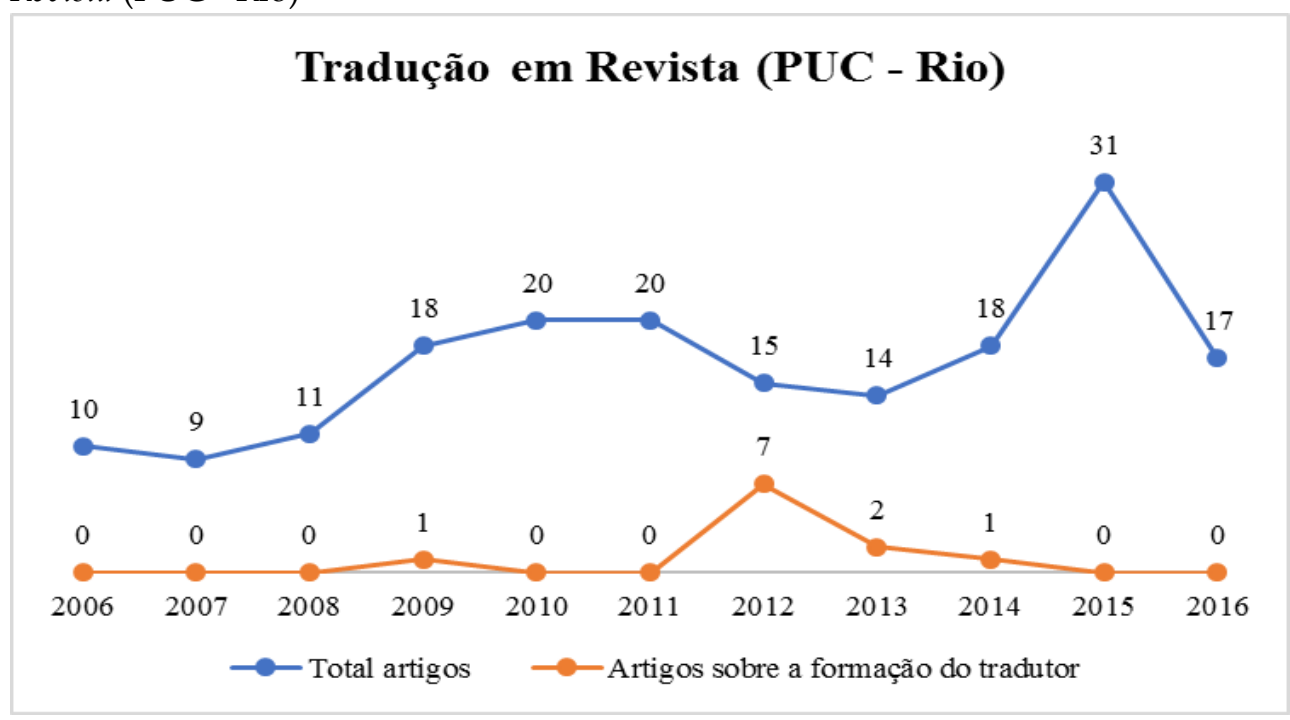

Elaboração: as autoras

Como pode ser observado no Quadro 6 e no Gráfico 7, 2012 foi o ano que mais teve publicações relativas à formação de tradutores, correspondendo a $44 \%$ do total publicado naquele ano. Essa discrepância com os demais anos é facilmente explicada, pois no segundo semestre de 2012 foi publicada uma edição especial intitulada Homenagem à Maria Candida Bordenave, organizada por Marcia Martins, Maria Paula Frota e Paulo Henriques Britto, todos professores do curso de Tradução da Pontifícia Universidade Católica do Rio de Janeiro.

Na apresentação do número 13, Martins, Frota e Britto destacam a importância de Bordenave para a área de Tradução e o seu ensino no Brasil. Bordenave, intérprete conferencista, formada pela Georgetown University, atuou na estruturação do Bacharelado em Tradução e Interpretação da PUCRio, o primeiro do país, motivo pelo qual pode ser considerada uma pioneira no ensino de Tradução no Brasil. A partir daí, organizou e realizou os dois primeiros Encontros Nacionais de Tradutores, em 1975 e em 1985, coordenou o GT de Tradução da ANPOLL em 1987 e criou a Especialização em Tradução da PUC-Rio em 1997 (MARTINS; FROTA; BRITTO, 2012, p. 1). Além disso, acreditamos que tenha defendido a primeira dissertação acerca 
da formação de tradutores no Brasil, intitulada "Contribuições da linguística para o ensino de Tradução", em 1976, orientada por Jürgen Heye na PUCRio.

A edição 13 (2012/2) da Tradução em Revista foi dividida em três partes: 1) artigos e palestras proferidas por Maria Candida Bordenave, um total de oito, sendo seis sobre o ensino de Tradução; 2) documentos de Bordenave (currículo, entrevista concedida à Cadernos de Tradução em 1998, parte de sua dissertação, conclusões e recomendações do I e do II Encontro Nacional de Tradutores e três fotos) e 3) depoimentos. Acreditamos que esse número especial em Homenagem à Maria Candida Bordenave, pioneira no ensino de Tradução no Brasil, é extremamente rico e importante para se traçar uma história da formação de tradutores no Brasil.

\section{Rónai - Revista de Estudos Clássicos e Tradutórios (UFJF)}

A revista Rónai foi criada em 2006 na Universidade Federal de Juiz de Fora, a título experimental, pelo professor Adauto Villela e era destinada aos graduandos com foco na Tradução. Com a saída desse professor, a revista permaneceu descontinuada até 2012, quando o professor Fábio Fortes sugeriu a sua reativação, juntamente com a expansão do escopo da revista para acolher os estudos clássicos. Assim, em 2013 foi publicado o primeiro número da Rónai - Revista de Estudos Clássicos e Tradutórios, com periodicidade semestral.

Assim, entre 2006 e 2016, foram publicadas nove edições, totalizando 73 artigos, entre os quais cinco sobre a temática da formação de tradutores (Quadro 7, Gráfico 8) - o que corresponde a 6,85\% do total.

Quadro 7 - Edições da Rónai - Revista de Estudos Clássicos e Tradutórios (UFJF) com artigos sobre aspectos da formação de tradutores

\begin{tabular}{|l|l|c|}
\hline \multicolumn{1}{|c|}{ Edição } & Total artigos & $\begin{array}{c}\text { Artigos sobre a } \\
\text { formação do tradutor }\end{array}$ \\
\hline 2006 (Ed. Piloto) & 12 & 1 \\
\hline 2013 (v. 1, n. 1) & 9 & 1 \\
\hline 2016 (v.4, n. 1) & 4 & 2 \\
\hline
\end{tabular}


2016 (v.4, n. 2)

15

1

Elaboração: as autoras

Gráfico 8 - Quantidade de artigos publicados por ano no periódico Rónai (UFJF)

\section{Rónai - Revista de Estudos Clássicos e Tradutórios (UFJF)}

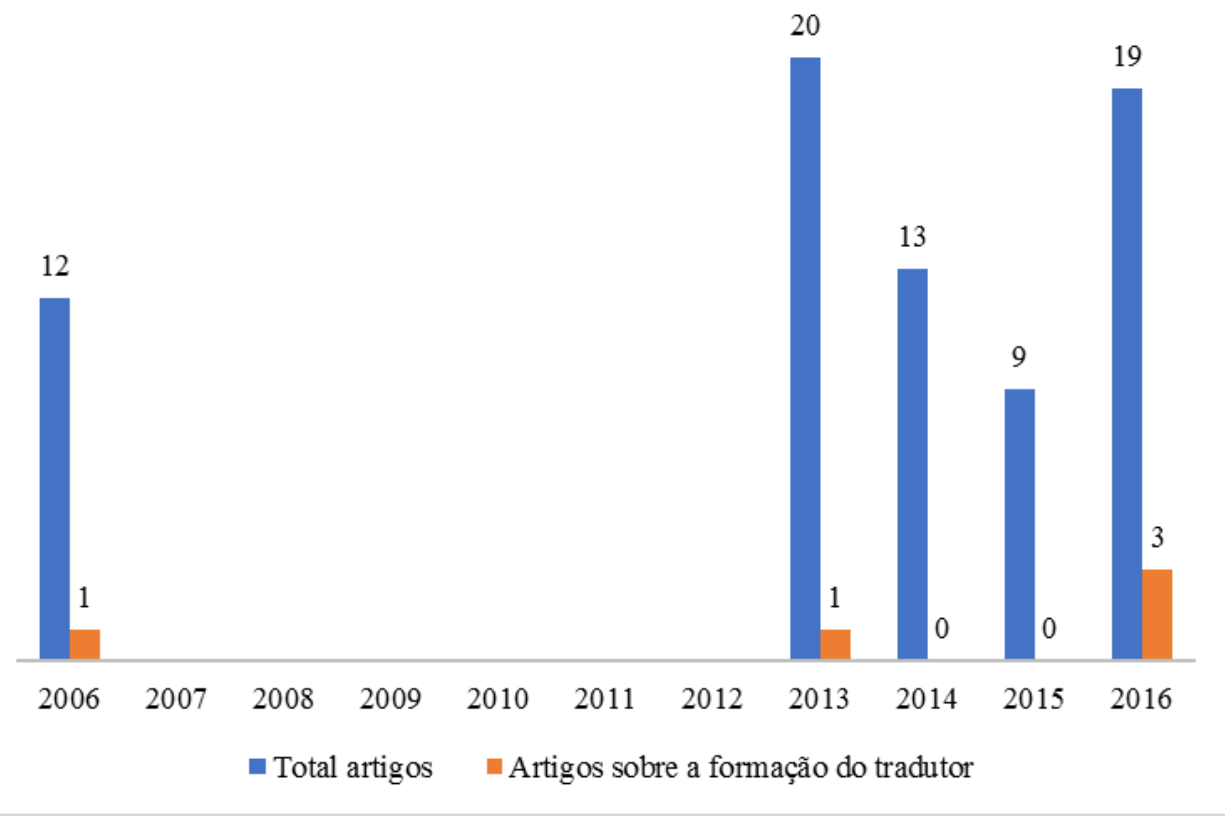

Elaboração: as autoras

\section{Traduzires (UnB)}

Criada em 2011, com a primeira publicação em 2012, a revista Traduzires da Universidade de Brasília (UnB), é fruto do então recém-criado Programa de Pós-Graduação em Estudos da Tradução (POSTRAD) da Universidade de Brasília (UnB). Traduzires teve sua publicação com periodicidade semestral entre 2012 e 2013. Desde 2014 a revista está descontinuada. Deste modo, nesses dois anos de atividades, a Traduzires publicou quatro edições, totalizando 31 artigos, dos quais quatro versam sobre a formação de tradutores (Quadro 8, Gráfico 9) - o que corresponde a 12,9\% do total. 
Quadro 8 - Edições da Traduzires (UnB) com artigos sobre aspectos da formação de tradutores

\begin{tabular}{|c|c|c|}
\hline Edição & Total artigos & $\begin{array}{l}\text { Artigos sobre a formação } \\
\text { do tradutor }\end{array}$ \\
\hline v.1, n.2 (2012) & 9 & 1 \\
\hline v.2, n.2(2013) & 8 & 3 \\
\hline
\end{tabular}

Elaboração: as autoras

Gráfico 9 - Quantidade de artigos publicados por ano no periódico Traduzires (UnB)

\section{Traduzires (UnB)}

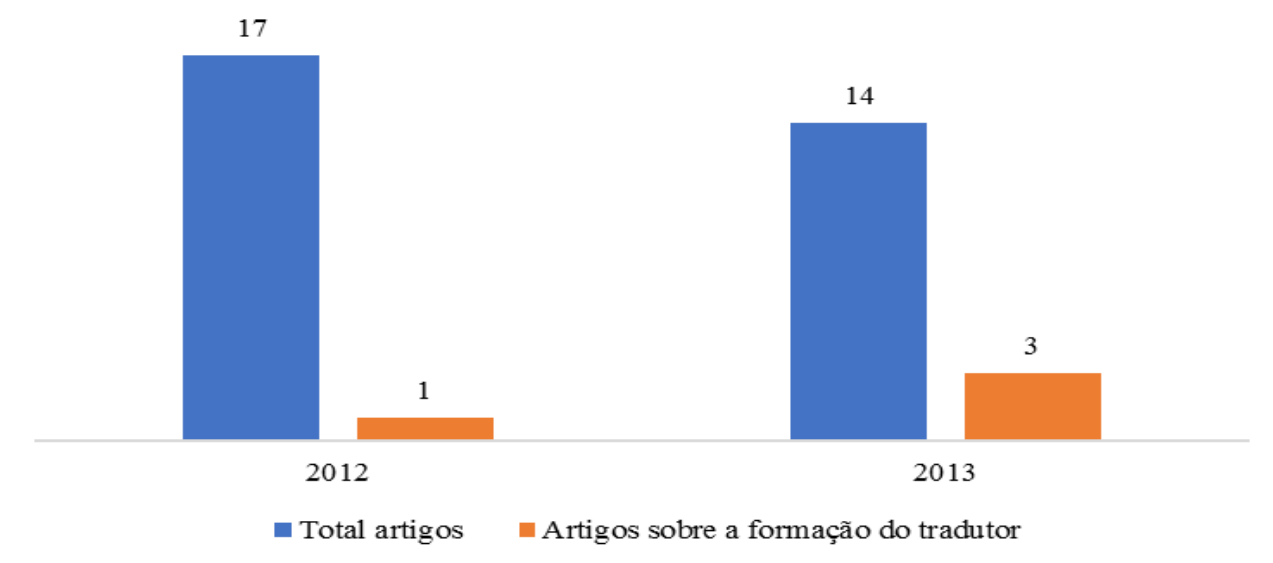

Elaboração: as autoras

\section{Belas Infiéis (UnB)}

Assim como a revista Traduzires, a Belas Infiéis foi criada em 2011 com a primeira publicação em 2012 no âmbito do recém-criado Programa de PósGraduação em Estudos da Tradução (POSTRAD/UnB). Com periodicidade semestral entre 2012 e 2018², a Belas Infiéis publicou 12 edições entre 2012 e 2016, totalizando 120 artigos, dos quais quatro discutem de alguma maneira a formação de tradutores (Quadro 9, Gráfico 10) e equivalem a 3\% dos artigos publicados.

2 A partir de 2019, a Revista Belas Infiéis passou a ter periodicidade trimestral (janeiro, abril, julho e outubro). 
Quadro 9 - Edições da Belas Infiéis (UnB) com artigos sobre aspectos da formação de tradutores

\begin{tabular}{|r|r|c|}
\hline Edição & Total & $\begin{array}{c}\text { Artigos sobre a formação do } \\
\text { tradutor }\end{array}$ \\
\hline v.3, n.2 (2014) & 11 & 1 \\
\hline v.4, n.2 (2015) & 10 & 2 \\
\hline v.5, n.1 (2016) & 13 & 1 \\
\hline
\end{tabular}

Elaboração: as autoras

Gráfico 10 - Quantidade de artigos publicados por ano no periódico Belas Infiéis $(\mathrm{UnB})$

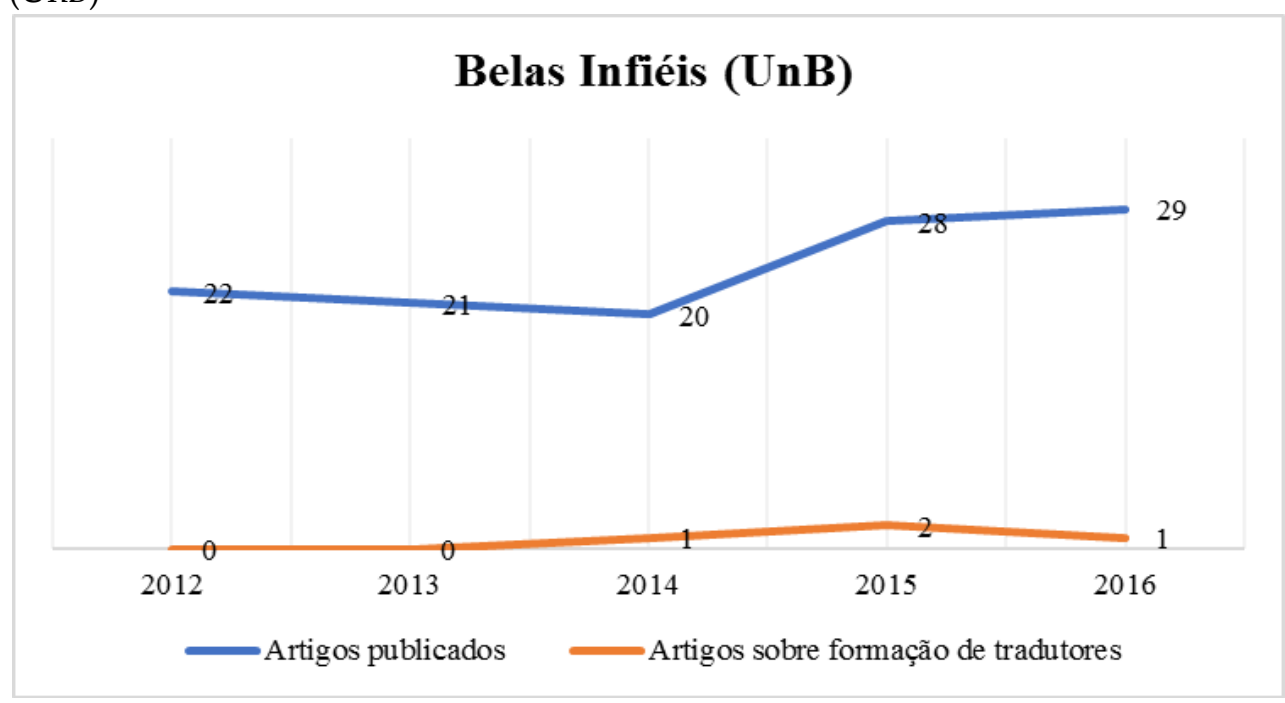

Elaboração: as autoras

Após termos apresentado dados quantitativos relacionados aos seis periódicos acadêmicos online brasileiros dedicados aos Estudos da Tradução aqui analisados, passaremos a discutir a escolha dos descritores utilizados para caracterizar e melhor identificar os textos publicados.

\section{A escolha de descritores: análise quanti-qualitativa}

Os Estudos da Tradução têm progredido desde a proposta de mapeamento da área por James Holmes (1988 [1972]) em seu artigo The Name and the Nature of Translation Studies. Por essa razão, conforme ressaltado por Pagano 
e Vasconcellos (2003, 2006) e Alves e Vasconcellos (2016), é de extrema importância que os pesquisadores conheçam os descritores, também conhecidos como indicadores, da área e os utilizem para melhor caracterizar suas publicações e, assim, estabelecer uma metalinguagem desse campo disciplinar que permita seu mapeamento e facilite "[...] a recuperação do conhecimento produzido na área [...]" (PAGANO; VASCONCELLOS, 2006, p. 211). O uso de termos ou vocabulário controlado, normalizado, permitiria a coerência da indexação das publicações, assim, diferentes textos sobre o mesmo assunto seriam encontrados em bases de dados com maior facilidade (PAGANO; VASCONCELLOS, 2006, 2003, ALVES; VASCONCELLOS, 2016).

Tal como proposto por Pagano e Vasconcellos $(2003,2006)$ e Alves e Vasconcellos (2016), acreditamos que a escolha das palavras-chave, juntamente com o título, permite ao leitor identificar melhor o tema do texto. Por essa razão, elencamos as palavras-chave e os títulos que permitiram a caracterização dos artigos dedicados à discussão da formação de tradutores.

Dos 1.243 artigos publicados pelos seis periódicos analisados, somente 61 tinham por temática a formação de tradutores e totalizam 212 palavras-chave (descritores). Destacamos que a inserção das palavras-chave para fins de indexação dos artigos não se deu de maneira uniforme, uma vez que alguns autores não indicaram palavras-chave e outros indicaram entre três e oito palavras-chave. Assim, ao analisarmos as 212 palavras-chave utilizadas pelos autores verificamos que 72 delas, isto é, 33,96\%, referiam-se ao ensino em geral e, dessas, somente 41 eram específicas à formação de tradutores $(19,34 \%)$.

Tal como listado por Pagano e Vasconcellos (2006, p. 220 - 222), percebemos que a escolha das palavras-chave estava circundada de alguns problemas como:

1) Uso de Tradução e Estudos da Tradução como palavras-chave uma vez que a publicação é realizada em periódicos da área estes descritores passam a ser irrelevantes como palavraschave; 
2) Uso de termos amplos ou o caráter vago das palavras-chave. Por vezes, os descritores escolhidos podem se referir a outros campos disciplinares;

3) Ausência de hierarquização entre as palavras-chave;

4) Ausência de padronização das palavras-chave, o que resulta em diferentes denominações para o mesmo tipo de investigação.

Como consequência dos problemas citados, percebemos que não ainda há um vocabulário estruturado e controlado, uma terminologia comum, para se referir à formação de tradutores que permita uma fácil e confiável recuperação das informações publicadas, bem como em poucos artigos é possível se verificar a organização hierárquica dos descritores.

Assim, identificamos as palavras-chave de cada artigo e realizamos o levantamento daquelas que possibilitam a classificação do artigo como sendo da temática da formação de tradutores (Gráfico 10, Quadro 10) de cada revista.

\section{TradTerm}

A revista TradTerm, como informado anteriormente, publicou, entre 1996 e 2016, 18 artigos sobre a formação de tradutores, totalizando 74 palavraschave (Gráfico 2). Os artigos não estavam padronizados em relação à quantidade de palavras-chave, que variaram entre três e sete palavras-chave. Dos 18 artigos, somente um não tinha como palavras-chave termos que indicavam a temática do ensino, porém seu título permite identificar seu tema, pois contém o termo "tradutor em formação". Das 74 palavras-chave escolhidas como descritores para a indexação dos artigos, somente 27 indicam que se trata da questão do ensino; dessas, 18 são tipificadas como relacionadas ao ensino de Tradução.

Já com relação aos títulos dos artigos publicados na TradTerm, somente dois não permitiam identificar que o texto tratava da formação de tradutores. 


\section{Cadernos de Tradução}

A revista Cadernos de Tradução, como informado anteriormente, publicou, entre 1996 e 2016, 21 artigos sobre o tema, totalizando 87 palavras-chave. Os artigos não apresentavam uniformidade em relação à quantidade de palavras-chave, que variaram entre zero e oito. Dos 21 artigos, um não tinha palavras-chave e quatro não tinham como palavras-chave termos que indicavam a questão do ensino, porém seu título permitia identificar seu tema. Das 87 palavras-chave escolhidas como metadados para a indexação dos artigos, somente 25 indicam que se trata da questão do ensino; dessas, 14 são tipificadas como relacionadas ao ensino de tradução. Além disso, somente quatro dos títulos dos artigos não permitiam identificar que o texto tratava da formação de tradutores.

\section{Tradução em Revista}

Os artigos publicados com a temática do ensino de Tradução na Tradução em Revista entre 2006 e 2016 foram 11, contabilizando 14 palavras-chave. Os artigos não apresentavam uniformidade em relação à quantidade de palavras-chave, sendo que seis artigos não possuíam palavras-chaves, três tinham três palavras-chave e somente um continha cinco palavra-chave. Dos 11 artigos, somente um possui palavras-chave que não se referem ao ensino. Das 14 palavras-chave escolhidas como metadados para a indexação dos artigos, somente cinco indicam que se trata da questão do ensino, dessas, quatro são tipificadas como relacionadas ao ensino de Tradução. Dos artigos publicados na Tradução em Revista, somente dois não permitiam serem identificados pelo título que o texto tratava da formação de tradutores.

\section{Rónai - Revista de Estudos Clássicos e Tradutórios}

A revista Rónai, como informado anteriormente, publicou, entre 2006 e 2016, cinco artigos sobre o tema, totalizando 15 palavras-chave. Os artigos não apresentavam uniformidade em relação à quantidade de palavras-chave; um artigo não tinha palavras-chave, um apresentou três palavras-chave, enquanto os três restantes apresentaram quatro palavras-chave. Das 15 palavras-chave escolhidas como descritores para a indexação dos artigos, 
somente três indicam que se trata da questão do ensino; dessas, uma é tipificada como relacionada ao ensino de Tradução. Dos cinco artigos publicados pela revista Rónai, somente dois não permitiram identificar que o texto tinha por temática a formação de tradutores.

\section{Traduzires}

Os quatro artigos com a temática "formação de tradutores" foram publicados na revista Traduzires em 2012 e 2013 e totalizaram 10 palavraschave. Os artigos não apresentavam uniformidade em relação à quantidade de descritores - um artigo não continha palavras-chave, dois indicavam três palavras-chave e um artigo informava quatro. Das 10 palavras-chave, somente quatro indicam que se trata da questão do ensino; dessas, três são tipificadas como relacionadas ao ensino de Tradução. Com relação aos títulos dos artigos publicados na Traduzires, todas as quatro publicações permitiram a identificação da temática do texto como sendo relativa à formação de tradutores.

\section{Belas Infiéis}

A revista Belas Infiéis, como informado anteriormente, publicou, entre 2012 e 2016, quatro artigos sobre o tema, com um total de 12 palavras-chave. Os artigos não apresentavam uniformidade em relação à quantidade de palavras-chave: em um não foi informado palavras-chave e os três restantes variaram entre três e cinco palavras-chave. Das 12 palavras-chave, somente oito indicam que se trata da questão do ensino; dessas, somente uma é tipificada como relacionada ao ensino de Tradução. Assim como no periódico Traduzires, os quatro artigos publicados pela Belas Infiéis podem ser identificados como relativos a alguma questão da formação de tradutores.

\section{Análise quanti-qualitativa geral dos descritores utilizados}

Entre os problemas citados por Pagano e Vasconcellos (2006) com relação à escolha das palavras-chave, destacamos: 1) a falta de padronização das palavras-chave, usa-se, por exemplo, Ensino de Tradução e Ensino da Tradução, Didática da Tradução, Processo de ensino e aprendizagem de 
Tradução, Treinamento de Tradutores, como referência à Formação de Tradutores, tal como destacado por Pagano e Vasconcellos (2006); 2) o uso de termos vagos, como Educação, Avaliação, Ensino, Temática, Ensinar e Aprender, 3) o uso de termos como Tradução e Estudos da Tradução em periódicos dedicados ao tema, o que os torna irrelevantes; 4) a falta de hierarquia das palavras-chave. Destacamos ainda a falta de padronização da quantidade de palavras-chaves dos artigos. Assim, em razão da falta de padronização e de hierarquização e do uso de termos vagos se torna difícil a identificação e recuperação dos artigos com a temática referente à formação de tradutores. Como podemos perceber no Gráfico 11, “a falta de padronização prejudica a coerência da indexação dando margem para uma diversidade pouco produtiva de representações de um mesmo assunto, a qual impossibilita a recuperação mais confiável de dados" (PAGANO; VASCONCELLOS, 2006, p. 228).

Gráfico 11 - Análise geral das palavras-chaves por periódicos acadêmicos dedicados aos Estudos da Tradução

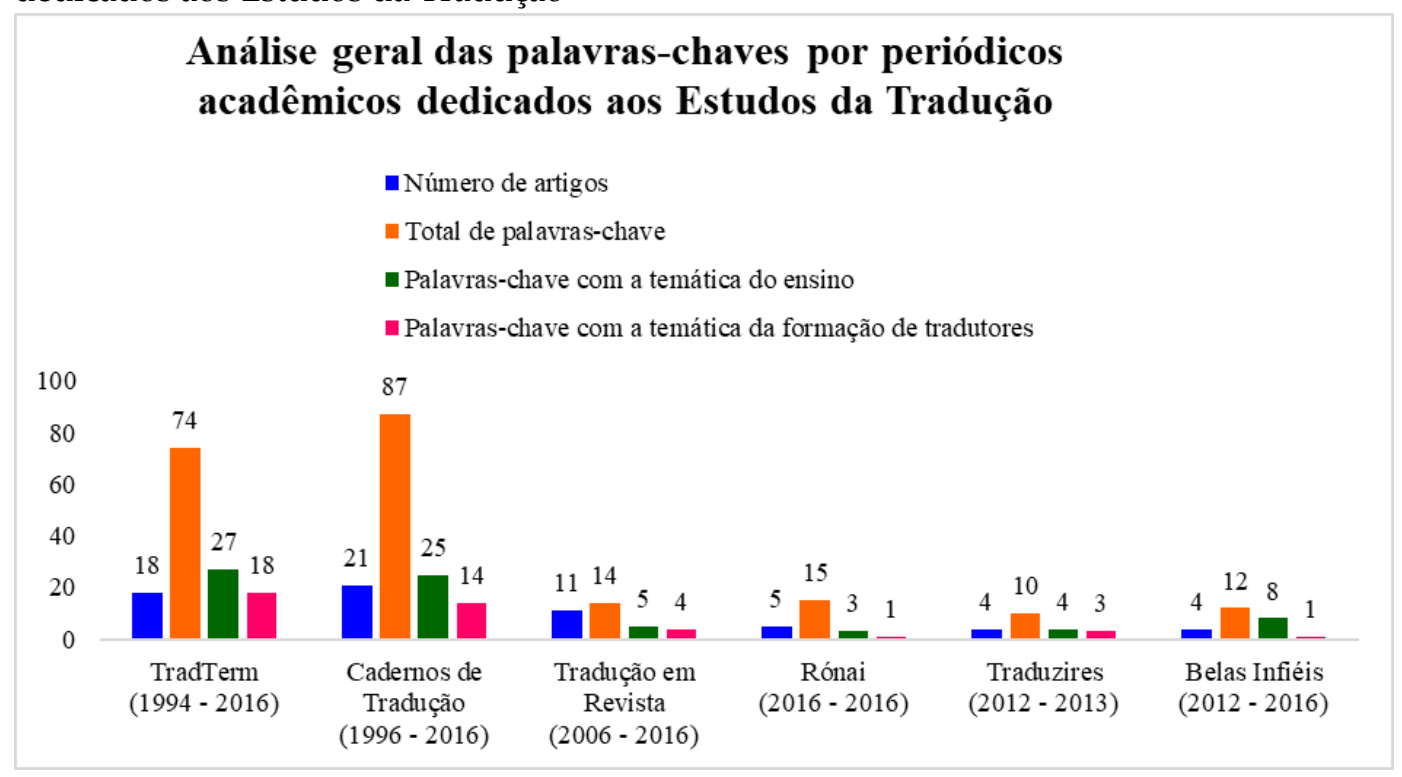

Elaboração: as autoras 
Tendo em vista o levantamento dos descritores (palavras-chave e títulos) utilizados pelos diversos autores em seus artigos publicados pelos periódicos acadêmicos brasileiros dedicados aos Estudos da Tradução (Quadro 10, Quadro 11), destacamos:

1) a importância da padronização dos descritores, como por exemplo:

a) Ensino de Tradução vs. Ensino da Tradução;

b) Ensino e aprendizagem de tradução $v s$. Ensino-aprendizagem de tradução vs. Ensino-aprendizagem da tradução;

2) ser premente pensar na hierarquização dos descritores da subárea "Formação de Tradutores", uma vez que podemos a partir dela pesquisar 1) Pedagogia da Tradução; 2) Didática da Tradução; 2) Ensino de Tradução; 3) Aprendizagem de Tradução; 4) Avaliação dos tradutores em formação; 5) Desenhos curriculares dos cursos de Tradução; 6) Elaboração de material didático; 7) Formação de formadores em Tradução; entre outros.

Quadro 10 - Palavras-chave que fazem referência ao ensino nos artigos analisados

\begin{tabular}{|c|c|c|c|c|c|}
\hline TradTerm & $\begin{array}{l}\text { Cadernos de } \\
\text { Tradução }\end{array}$ & $\begin{array}{l}\text { Tradução em } \\
\text { Revista }\end{array}$ & Rónai & Traduzires & Belas Infiéis \\
\hline $\begin{array}{l}\text { Ensino de } \\
\text { Tradução }\end{array}$ & $\begin{array}{l}\text { Ensino de } \\
\text { Tradução }\end{array}$ & $\begin{array}{l}\text { Ensino de } \\
\text { tradução }\end{array}$ & Ensino & $\begin{array}{l}\text { Ensino de } \\
\text { tradução }\end{array}$ & $\begin{array}{l}\text { Ensino de } \\
\text { tradução }\end{array}$ \\
\hline $\begin{array}{l}\text { Didática da } \\
\text { Tradução }\end{array}$ & $\begin{array}{l}\text { Cursos de } \\
\text { tradução }\end{array}$ & $\begin{array}{l}\text { Ensino e } \\
\text { aprendizagem } \\
\text { de tradução }\end{array}$ & $\begin{array}{l}\text { Didática da } \\
\text { tradução }\end{array}$ & $\begin{array}{l}\text { Formação de } \\
\text { tradutores por } \\
\text { objetivos de } \\
\text { aprendizagem }\end{array}$ & $\begin{array}{l}\text { Abordagem } \\
\text { pedagógica } \\
\text { popular }\end{array}$ \\
\hline $\begin{array}{l}\text { Formação de } \\
\text { tradutores }\end{array}$ & $\begin{array}{l}\text { Didática da } \\
\text { Tradução }\end{array}$ & $\begin{array}{l}\text { Graduação em } \\
\text { Tradução }\end{array}$ & $\begin{array}{l}\text { Jovens } \\
\text { tradutores }\end{array}$ & $\begin{array}{l}\text { Enfoque por } \\
\text { tarefas de } \\
\text { tradução }\end{array}$ & Autoavaliação \\
\hline $\begin{array}{l}\text { Treinamento } \\
\text { de tradutores }\end{array}$ & $\begin{array}{l}\text { Ensino- } \\
\text { aprendizagem } \\
\text { de tradução }\end{array}$ & $\begin{array}{l}\text { Professores de } \\
\text { tradução }\end{array}$ & & $\begin{array}{l}\text { Terminologia e } \\
\text { ementa } \\
\text { curricular }\end{array}$ & Construtivismo \\
\hline
\end{tabular}




\begin{tabular}{|c|c|c|c|}
\hline $\begin{array}{l}\text { Aprendizado } \\
\text { de tradução }\end{array}$ & $\begin{array}{l}\text { Formação de } \\
\text { tradutores }\end{array}$ & $\begin{array}{l}\text { Crenças de } \\
\text { alunos- } \\
\text { ingressantes }\end{array}$ & Emergentismo \\
\hline PACTE & $\begin{array}{l}\text { Pedagogia da } \\
\text { tradução }\end{array}$ & & $\begin{array}{l}\text { Empirismos- } \\
\text { racionalismo }\end{array}$ \\
\hline $\begin{array}{l}\text { Teoria e } \\
\text { prática da } \\
\text { tradução }\end{array}$ & $\begin{array}{l}\text { Translator } \\
\text { education }\end{array}$ & & $\begin{array}{l}\text { Epistemologia } \\
\text { pedagógica }\end{array}$ \\
\hline $\begin{array}{l}\text { Processo de } \\
\text { ensino- } \\
\text { aprendizage } \\
\mathrm{m}\end{array}$ & $\begin{array}{l}\text { Teoria e } \\
\text { prática da } \\
\text { tradução }\end{array}$ & & Perfil dos alunos \\
\hline $\begin{array}{l}\text { Desenho de } \\
\text { material } \\
\text { didático }\end{array}$ & $\begin{array}{l}\text { Abordagem } \\
\text { cognitivo- } \\
\text { discursiva }\end{array}$ & & \\
\hline $\begin{array}{l}\text { Conteúdo } \\
\text { programático }\end{array}$ & $\begin{array}{l}\text { Aprendizagem } \\
\text { por objetivos }\end{array}$ & & \\
\hline $\begin{array}{l}\text { Experiências } \\
\text { didáticas }\end{array}$ & Avaliação & & \\
\hline Avaliação & Currículos & & \\
\hline $\begin{array}{l}\text { Avaliação de } \\
\text { qualidade }\end{array}$ & $\begin{array}{l}\text { Currículos } \\
\text { universitários }\end{array}$ & & \\
\hline \multirow[t]{5}{*}{ Educação } & $\begin{array}{l}\text { Design } \\
\text { curricular }\end{array}$ & & \\
\hline & $\begin{array}{l}\text { Ensinar e } \\
\text { aprender }\end{array}$ & & \\
\hline & $\begin{array}{l}\text { Ensino } \\
\text { superior }\end{array}$ & & \\
\hline & Ensino & & \\
\hline & $\begin{array}{l}\text { Pesquisadores } \\
\text { em formação }\end{array}$ & & \\
\hline
\end{tabular}




\section{Tarefas de \\ resolução de \\ problemas}

Elaboração: as autoras

Quadro 11 - Termos referentes ao ensino nos títulos dos artigos analisados

\begin{tabular}{|c|c|c|c|c|c|}
\hline TradTerm & $\begin{array}{l}\text { Cadernos de } \\
\text { Tradução }\end{array}$ & $\begin{array}{l}\text { Tradução em } \\
\text { Revista }\end{array}$ & Rónai & Traduzires & Belas Infiéis \\
\hline $\begin{array}{l}\text { Aprendiz de } \\
\text { tradução }\end{array}$ & $\begin{array}{l}\text { Didáctica de la } \\
\text { traducción }\end{array}$ & $\begin{array}{l}\text { Cursos de } \\
\text { tradução }\end{array}$ & $\begin{array}{l}\text { Didática da } \\
\text { tradução }\end{array}$ & $\begin{array}{l}\text { Abordagem } \\
\text { por tarefa de } \\
\text { tradução }\end{array}$ & $\begin{array}{l}\text { Alumno de } \\
\text { traducción }\end{array}$ \\
\hline $\begin{array}{l}\text { Cursos de } \\
\text { tradução }\end{array}$ & $\begin{array}{l}\text { Ensino de } \\
\text { terminologia } \\
\text { para } \\
\text { tradutores }\end{array}$ & $\begin{array}{l}\text { Ensino de } \\
\text { tradução }\end{array}$ & $\begin{array}{l}\text { Jovens } \\
\text { tradutores }\end{array}$ & $\begin{array}{l}\text { Didáctica de } \\
\text { la traducción }\end{array}$ & $\begin{array}{l}\text { Ensino de } \\
\text { tradução }\end{array}$ \\
\hline $\begin{array}{l}\text { Enseñanza de } \\
\text { traducción }\end{array}$ & $\begin{array}{l}\text { Ensino de } \\
\text { tradução }\end{array}$ & $\begin{array}{l}\text { Formação de } \\
\text { tradutores e } \\
\text { intérpretes }\end{array}$ & Ensino & $\begin{array}{l}\text { Ensino de } \\
\text { tradução }\end{array}$ & $\begin{array}{l}\text { Formação do } \\
\text { tradutor }\end{array}$ \\
\hline $\begin{array}{l}\text { Ensino de } \\
\text { tradução }\end{array}$ & $\begin{array}{l}\text { Ensino } \\
\text { politécnico da } \\
\text { tradução }\end{array}$ & $\begin{array}{l}\text { Formação de } \\
\text { tradutor }\end{array}$ & & $\begin{array}{l}\text { Formação de } \\
\text { tradutores }\end{array}$ & $\begin{array}{l}\text { Abordagens } \\
\text { cognitiva e } \\
\text { metacognitiva }\end{array}$ \\
\hline $\begin{array}{l}\text { Formação de } \\
\text { tradutores }\end{array}$ & $\begin{array}{l}\text { Ensino } \\
\text { universitário } \\
\text { da tradução }\end{array}$ & $\begin{array}{l}\text { Formação de } \\
\text { tradutores }\end{array}$ & & $\begin{array}{l}\text { Desenho de } \\
\text { ementa de } \\
\text { disciplina }\end{array}$ & Autoavaliação \\
\hline $\begin{array}{l}\text { Tradutor em } \\
\text { formação }\end{array}$ & $\begin{array}{l}\text { Institucionaliz } \\
\text { ação da } \\
\text { tradução no } \\
\text { Brasil }\end{array}$ & $\begin{array}{l}\text { Metodologia } \\
\text { de ensino de } \\
\text { tradução }\end{array}$ & & & Aprendizagem \\
\hline $\begin{array}{l}\text { Apontamentos } \\
\text { didáticos }\end{array}$ & $\begin{array}{l}\text { Pedagogia da } \\
\text { Tradução }\end{array}$ & $\begin{array}{l}\text { Tradutor em } \\
\text { formação }\end{array}$ & & & \\
\hline
\end{tabular}




\begin{tabular}{|l|l|l|l|l|}
\hline Aprendiz & $\begin{array}{l}\text { Translator } \\
\text { education }\end{array}$ & $\begin{array}{l}\text { Translation } \\
\text { teaching }\end{array}$ & & \\
\hline Didática & Ensino & & & \\
Ensinar & & & & \\
Pesquisa em & & & & \\
sala de aula & & & & \\
\hline $\begin{array}{l}\text { Projeto de } \\
\text { ensino }\end{array}$ & & & & \\
\hline $\begin{array}{l}\text { Proposta } \\
\text { didática }\end{array}$ & & & & \\
\hline $\begin{array}{l}\text { Unidade } \\
\text { didática }\end{array}$ & & & \\
\hline
\end{tabular}

Elaboração: as autoras

Acreditamos que ao padronizarmos e hierarquizarmos os descritores dedicados à subárea "Formação de Tradutores", reduziremos o uso de termos vagos, bem como dos descritores Tradução e Estudos da Tradução. Deste modo, esse levantamento e mapeamento da subárea formação de tradutores busca ser uma resposta inicial ao chamado de Pagano e Vasconcellos (2006, p. 223) pela publicação de outros mapas relacionados aos Estudos da Tradução que visem "enriquecer o debate e conduzir à elaboração de hierarquias conceituais passíveis de integrarem um repertório que oriente o pesquisador - tanto em formação quanto consolidado - quando da definição de palavras-chave para sua pesquisa".

\section{Considerações finais}

Empreendemos o mapeamento em um discurso acadêmico em constante renovação, aquele dos artigos publicados em periódicos acadêmicos, que é resultado não somente de pesquisas de mestrado e doutorado, mas também, por vezes, de pesquisas ligadas a grupos vinculados também à graduação, ou ainda de interesse próprio, o qual dialoga diretamente com a proposta de Pagano e Vasconcellos (2003). 
Sabemos que a metalinguagem dos Estudos da Tradução é discutida e utilizada nos bacharelados em Tradução, mas esta tem se inserido cada vez mais nos cursos de Letras, o que merece especial atenção e interesse. Além disso, acreditamos que, quando ofertada, a disciplina "Metodologia de Pesquisa em Estudos da Tradução" é um dos vários locais passíveis de discussão da metalinguagem, pois é a partir desta disciplina que (pós)graduandos se debruçam na (re)construção de seus projetos de pesquisa, o que passa certamente pelo questionamento de suas palavraschave, de seus títulos e pela localização de sua pesquisa em meio ao campo disciplinar dos Estudos da Tradução.

Desse modo, nossa pesquisa apresenta uma análise da evolução e do cenário de reflexão acerca da formação de tradutores no gênero do discurso acadêmico artigo e uma chamada à busca de uma metalinguagem comum, assim como enfatizado por Pagano e Vasconcellos (2006), para os Estudos da Tradução, mais especificamente à formação de tradutores. Visa ainda ser uma contribuição para a história da formação de tradutores no Brasil.

Em suma, dos 1.243 artigos publicados de 1996 a 2016 em periódicos acadêmicos brasileiros dedicados aos Estudos da Tradução, somente 61 artigos podem ser caracterizados como fontes de discussão sobre a formação de tradutores, o que corresponde a somente $4,91 \%$ do total. Nosso período de levantamento de dados cobre o período de 1996 a 2016; são 20 anos de publicações, o que, se tivéssemos os periódicos criados à mesma época, daria uma média de publicações de 62 artigos por ano. Considerado a média de 62 artigos por ano, chama a atenção o fato de que o ensino de tradução tenha sido tema de somente 61 artigos de um total de 1.243, o que equivaleria, portanto, a um ano do total das publicações.

Chama atenção ainda mais a partir do momento em que ao realizar busca por assunto na Plataforma Lattes pelas palavras-chave "Formação de tradutores", "Ensino de Tradução", "Pedagogia da Tradução", "Didática da Tradução", "tradutor(es) em formação" e "treinamento de tradutores", há um grande número de ocorrências. Isto é, interesse pelo tema aparenta ter aumentado, porém a produção em formato de artigos não condiz com a expectativa. Destacamos ainda que desde a defesa da primeira dissertação tendo por temática o Ensino de Tradução, em 1976, até 2016 foram 
publicados 20 dissertações e oito teses sobre a formação de tradutores no Brasil (COSTA, 2018, p. 217 - 223).

Vale ressaltar ainda uma possível ferramenta de buscas de artigos, o Google Acadêmico; não a utilizamos nessa investigação inicial por não restringir seus resultados a periódicos específicos da área. Assim, ao inserir o termo de busca "Formação de tradutores" encontramos 823 resultados, tendo por filtros o período de 1996 a 2006 e considerando as páginas em português. Ressaltamos ainda que desconsideramos como levantamento inicial desta pesquisa os artigos sobre a formação de intérpretes, a formação de tradutores e/ou intérpretes de língua de sinais e a formação de audiodescritores. Além disso, verificamos que outros periódicos, sem escopo específico aos Estudos da Tradução, publicaram artigos sobre formação de tradutores, tais como: DELTA - Documentação de Estudos em Linguística Teórica e Aplicada (PUC-SP); Intercâmbio. Revista do Programa de Estudos Pós-Graduados em Linguística Aplicada e Estudos da Linguagem (PUC-SP); Scripta (PUC-MG); Gragoatá (UFF); Travessias: Pesquisas em Educação, Cultura, Linguagem e Arte (Unioeste); Revista de Letras (UFC); Abehache: Revista da Associação Brasileira de Hispanistas; Revista do GEL: Grupo de Estudos Linguísticos do Estado de São Paulo, entre outros.

Por fim, esperamos ter colaborado para a discussão acerca da formação de tradutores e dos parâmetros de escolha de descritores para os Estudos da Tradução nessa subárea e que esta contribuição auxilie para delinear uma história da formação de tradutores no Brasil.

\section{Referências}

ALVES, D. A. de S.; VASCONCELLOS, M. L. Metodologia de pesquisa em Estudos da Tradução: uma análise bibliométrica de teses e dissertações produzidas no Brasil entre 2006-2010. D.E.L.T.A., São Paulo, v. 32, n. 2, p. 375-404, 2016. Disponível em:

http://www.scielo.br/scielo.php?script=sci_arttext\&pid=S010244502016000200375\&lng=pt\&nrm=iso\&tlng=pt Acesso: junho 2019. AZENHA JÚNIOR, João. Apresentação. TradTerm, São Paulo, v. 4, n. 1, p. 7 - 10, 1997. Disponível em: 
http://www.revistas.usp.br/tradterm/article/view/49866/53965 Acesso em: junho 2019.

BRASIL. Lei no 5.540, de 28 de novembro de 1968. Disponível em: http://www2.camara.leg.br/legin/fed/lei/1960-1969/lei-5540-28-novembro1968-359201-publicacaooriginal-1-pl.html. Acesso em: junho 2019.

COSTA, Patrícia Rodrigues. A formação de tradutores em instituições de educação superior públicas brasileiras: uma análise documental. 2018. (Tese de doutorado em Estudos da Tradução). Florianópolis: Universidade Federal de Santa Catarina, 2018. Disponível em: https://repositorio.ufsc.br/handle/123456789/188094 Acesso em: junho 2019. COSTA, Patrícia Rodrigues. GUERINI, Andréia. PEREIRA, Germana Henriques. A formação de tradutoras e tradutores de línguas orais (Português/Inglês) no Brasil: um estudo das diferentes concepções curriculares. Mutatis Mutandis, Antioquia, Colombia, v. 12, n. 1, p. 51-77, 2019. Disponível em:

http://aprendeenlinea.udea.edu.co/revistas/index.php/mutatismutandis/arti cle/view/337367 Acesso: junho 2019.

FROTA, P.; BRITTO, H.; MARTINS, D. A. P. Apresentação - Maria Candida Bordenave e a Tradução no Brasil. Tradução em Revista, Rio de Janeiro, 2, 2012. Disponível em:

https://www.maxwell.vrac.puc-

rio.br/rev_trad.php?strSecao=fasciculo\&fas $=27146 \& N r S e c a o=1 . \quad$ Acesso: junho 2019.

HOLMES, James. S. The Name and Nature of Translation Studies. In: Translated! Papers on Literary Translation and Translation Studies. Amsterdam: Rodopi, 1988 [1972].

PAGANO, Adriana; VASCONCELLOS, Maria Lúcia Barbosa de. Apresentação. Cadernos de Tradução, Florianópolis, v.1, n. 17, p. 9 - 17, 2006. Disponível em:

https://periodicos.ufsc.br/index.php/traducao/article/view/6852/6405

Acesso: junho 2019.

PAGANO, Adriana; VASCONCELLOS, Maria Lúcia Barbosa de. Estudos da tradução no Brasil: reflexões sobre teses e dissertações elaboradas por 
pesquisadores brasileiros nas décadas de 1980 e 1990. DELTA, São Paulo, v. 19, p. 1-25, 2003. Disponível em:

http://www.scielo.br/pdf/delta/v19nspe/03.pdf. Acesso: junho 2019.

PAGANO, Adriana; VASCONCELLOS, Maria Lúcia Barbosa de. "Formando" Futuros pesquisadores: palavras-chave e afiliações teóricas no campo disciplinar Estudos da Tradução. Cadernos de Tradução, Florianópolis, v.1, n. 17, p. 9 - 17, 2006. Disponível em:

https://periodicos.ufsc.br/index.php/traducao/article/view/6863/6414

Acesso: junho 2019.

Periódicos acadêmicos online brasileiros dedicados aos Estudos da Tradução

Cadernos de Literatura em Tradução. Disponível em:

http://www.revistas.usp.br/clt/issue/archive

Cadernos de Tradução (UFRGS). Disponível em:

https://seer.ufrgs.br/cadernosdetraducao

Cadernos de Tradução (UFSC). Disponível em:

https://periodicos.ufsc.br/index.php/traducao/index

In-Traduções. Disponível em:

http://incubadora.periodicos.ufsc.br/index.php/intraducoes

Non plus. Disponível em:

https://www.revistas.usp.br/nonplus

Revista Belas Infiéis. Disponível em:

http://periodicos.unb.br/index.php/belasinfieis

Ronái - Revista de Estudos Clássicos e Tradutórios. Disponível em:

https://periodicos.ufjf.br/index.php/ronai

Scientia Traductionis. Disponível em:

https://periodicos.ufsc.br/index.php/scientia

TradTerm. Disponível em:

https://www.revistas.usp.br/tradterm

Tradução \& Comunicação: Revista Brasileira de Tradutores. Disponível em: http://revista.pgsskroton.com.br/index.php/traducom

Tradução em Revista. Disponível em: 
https://www.maxwell.vrac.puc-

rio.br/rev_trad.php?strSecao $=$ sobre $\&$ fas $=\&$ menufas $=1$

Traduzires. Disponível em: http://periodicos.unb.br/index.php/Traduzires

Translatio. Disponível em: https://seer.ufrgs.br/translatio

Transversal. Disponível em: http://www.periodicos.ufc.br/Transversal

\title{
Resumo
}

A formação de tradutores(as) em universidades brasileiras tornou-se possível após a publicação da Lei de Diretrizes e Bases de 1968. Além disso, desde a década de 1970 tem-se pesquisado sobre o tema em programas de pós-graduação brasileiros. A partir disso, buscamos responder à pergunta: "O que temos publicado sobre formação de tradutores nos periódicos dedicados aos Estudos da Tradução no Brasil?". Este artigo visa apresentar o mapeamento dos artigos acerca da formação de tradutores publicados em periódicos acadêmicos brasileiros online da área dos Estudos da Tradução no período de 1996 a 2016, para discutir a escolha dos descritores e sua indexação e contribuir para a história da formação de tradutores no Brasil.

Palavras-chave: Periódicos brasileiros; Artigos; Formação de Tradutores; Descritores.

\begin{abstract}
Translator education in Brazil became possible after the enactment of the Law number 5,540 of November 28 1968, which granted more autonomy for higher education institutions in creating courses. In addition, since the 1970s researches on this subject have been conducted in Brazilian graduate programs. Thereafter, we seek to answer the question: "What have we published about translator education in academic journals of the field in Brazil?" Hence, this article aims to present a survey and mapping of articles regarding translator training published in Brazilian online academic journals of Translation Studies and to discuss the selection of descriptors as indexing terms and to contribute to the history of translator education in Brazil.
\end{abstract}

Keywords: Brazilian Academic Journals; Articles; Translator Education; Descriptors. 